\title{
Cloning, Transformation and Expression of Human Interferon $\alpha 2 b$ Gene in Tobacco Plant (Nicotiana tabacum cv. xanthi)
}

\author{
Shahrzad Ahangarzadeh ${ }^{1,2}$, Mohammad Hosein Daneshvar ${ }^{1}$, Hamid Rajabi-Memari ${ }^{3^{*}}$, Ha- \\ mid Galehdari ${ }^{4}$, Khalil Alamisaied ${ }^{1}$ \\ ${ }^{1}$ Department of Agricultural Biotechnology, University of Agriculture and Natural Resources, Ahwaz, IR Iran \\ ${ }^{2}$ Department of Cellular and Molecular Biology Research Center, Shahid Beheshti University of Medical Sciences, Tehran, IR Iran \\ ${ }^{3}$ Department of Agronomy and Plant Breeding, Shahid Chamran University, Ahwaz, IR Iran \\ ${ }^{4}$ Department of Genetics, Shahid Chamran University, Ahwaz, IR Iran
}

\section{A R T I C L E I N F O}

Article type:

Original Article

Article history:

Received: 02 Dec 2011

Revised: 26 Feb 2012

Accepted: 06 Jun 2012

Keywords:

Molecular Farming

Interferons

Tobacco

DNA Transformation Competence Agrobacterium

\begin{abstract}
A B S T R A C T
Background: Molecular farming is the production of important recombinant proteins in transgenic organisms on an agricultural scale. Interferons are proteins with antiviral and antitumor activities and can be used for viral infections and cancers treatments.

objectives: This study reports the transformation of INF $\alpha 2 \mathrm{~b}$ gene in tobacco plant for the first time in Iran.

Materials and Methods: Interferon $\alpha 2 b$ gene was amplified by PCR using specific primers containing appropriate restriction enzymes, plant highly expression sequence and Histidine tag sequence. Target sequence was cloned in plant expression vector PCAMBIA1304 and the construct named PCAMINF $\alpha$. pCAMINF $\alpha$ was transferred to E. coli strain DH5 $\alpha$ and plated on LB agar medium containing kanamycin 50 mgl-1. The colonies were confirmed by colony PCR and sequencing. The construct was transferred into Agrobacterium tumefaciens by freeze-thaw method and transformed colonies were confirmed by colony PCR. Tobacco plants (cultivar xanthi) were inoculated with A. tumefaciens strain LBA4404 by leaf disc method. Inoculated explants were cultured on MSII (MS + BAP 1mgl-1 + NAA $0.1 \mathrm{mgl}-1)$ at $28^{\circ} \mathrm{C}$ and darkness for 48 hours. Then explants were transferred to selection medium containing cephotaxime (250 mgl-1) and hygromycin (15 mgl-1) in a 16/8 (day/night) h photoperiod in growth room with an irradiance of 5000 lux. Transgenic plants were regenerated and transferred to perlite. Genomic DNA was extracted from regenerated plants by Dellaporta method at 5-leaf step and transgenic lines were confirmed by PCR with specific primers. Expression of Interferon $\alpha 2 \mathrm{~b}$ gene was confirmed by dot blotting.

Conclusions: Since no report of interferon alpha production in plants in Iran has been expressed yet, this research could create a field of producing this drug in tobacco, in Iran.
\end{abstract}

Published by DocS. 2012. cc 3.0.

Implication for health policy/practice/research/medical education:

This study reports the transformation of INF $\alpha 2 \mathrm{~b}$ gene in tobacco plant.

Please cite this paper as:

Ahangarzadeh Sh, Daneshvar MH, Rajabi-Memari H, Galehdari, H, Alamisaied Kh. Cloning, Transformation and Expression of Human Interferon $\alpha 2$ b Gene in Tobacco Plant (Nicotiana tabacum cv. xanthi).Jundishapur J Nat Pharm Prod. 2012:7(3);111-6.

\footnotetext{
* Corresponding author: Hamid Rajabi-Memari, Department of Agronomy and Plant Breeding, Shahid Chamran University, Ahwaz, IR Iran. Tel:+98-02123872552. E-mail:memari@scu.ac.ir

(C) 2012 School of Pharmacy, Ahvaz Jundishapur University of Medical Sciences; Published by DocS.

This is an Open Access article distributed under the terms of the Creative Commons Attribution License (http://creativecommons.org/licenses/by/3.0), which permits unrestricted use, distribution, and reproduction in any medium, provided the original work is properly cited.
} 


\section{Background}

Molecular farming is the production of important recombinant proteins in transgenic organisms on an agricultural scale. While plants have been used as a source of medicinal compounds for so long, molecular farming represents a new source of molecular medicines, such as providing some important compounds like plasma proteins, enzymes, growth factors, vaccines and recombinant antibodies, whose medical benefits are well understood (1). production of foreign proteins in plants has numerous advantages including ease of genetic manipulations, efficiency of the transformation technology, speed of scale up, lack of potential contamination with human pathogens such as HIV, prions, hepatitis viruses, etc., conservation of eukaryotic cell machinery mediating protein modification and finally low cost of biomass production (2). Human IFN- $\alpha$ is an extracellular signal protein secreted by body cells when cells stimulated by viruses, microorganisms, foreign cells, foreign macromolecules, or various other chemical compounds (3-5). Then, IFN- $\alpha$ increases the defensive functions in their surrounding cells; these functions may regulate viruses replication, the immune responses, or cells growth $(6,7)$. Several cDNA clones of IFN- $\alpha$ have been isolated and expressed in prokaryotic cells and mammalian cells to prepare recombinant IFN $\alpha$ for clinical use $(8,9)$. Nowadays, clinical IFN preparations are used for anticancer and antiviral therapies (10).

The Food and Drug Administration first approved a particular subtype of interferon- $\alpha$ (IFN $\alpha 2 b$ ) in 1986 for the treatment of hairy cell leukemia in the United States. The recombinant IFN $\alpha 2 \mathrm{~b}$ now on the market is produced using an E. coli expression system (2). Tobacco is a model plant system in molecular farming for last two decades. It has many advantages compared to other plants such as ease of gen transformation and tissue culture, high seeds number and huge amount of biomass (11), and the existence of many suitable expression vector for increasing of expression of interested genes. The high yield (one hundred tons per hectare of leaf product) and availability of different tobacco expression platform like plastid, transient and stable nuclear expression systems has made this plant as a good candidate for molecular farming research. Since this plant is not considered as food and feed crop it reduce the possibility of environmental contamination by tobacco transgenic lines (2). Transfer of foreign genes into higher plants mediated by Agrobacterium tumefaciens is a standard technique in plant molecular biology and genetic engineering (12). For many different plant species, it is possible to obtain transgenic plants after Agrobacterium mediated DNA transformation (13). Agrobacterium mediated transformation has been successfully exploited in many researches and increase the level of regeneration of normal plants (12).

\section{Objectives}

In this communication, we reported the transformation of INF $\alpha 2 b$ gene in tobacco and based on our knowledge, this work is the first research report of transformation of INF $\alpha 2 b$ gene in tobacco, in Iran.

\section{Materials and Methods}

\subsection{Bacteria}

Escherichia coli strain DH5 $\alpha$ was used as a host for maintaining and proliferating the construct and Agrobacterium tumefaciens strain LBA4404 for transformation of the INF $\alpha 2 b$ gene to tobacco. The bacteria were provided by Dr. Mokhtar Jalali from Tarbiat Modarres University, Tehran, Iran.

\subsection{Primers}

The appropriate primers were designed considering plant high expression sequence (Kozak sequence), INF $\alpha 2 \mathrm{~b}$ gene both sides, adequate restriction sites, His Tag sequence to detect expression and purification and factor Xa for removing His Tag sequence. These specific primers were used for amplification of this gene. The nucleotide sequences of the primers were as follow: Forward Primer:

$5^{` C A T G C C A T G G C A C A T C A T C A T C A T C A T C A T C A A C A A T-~}$ GTGATCTGCCTCAAACC-3' contained NcoI recognition site and reverse primer: 5'CATCAGGGTCACCCTATTATT TCCTTATTCTTAAACTTTC-3` contained recognition site for BstEII.

Vector:

Plant expression vector pCAMBIA1304 (CAMBIA Co. Australia) was used which carries kanamycin-resistance gene for selection of the colonies of the bacteria and hygromycin-resistance gene for the transgenic lines. This vector carries LB and RB (Left and Right Borders for integration of foreign genes into host genome, CaMV35s, (Cauliflower Mosaic Virus promoter which induces high level of transcription), NcoI and BstEII restriction sites and NOS, (Nopaline Synthase terminator which induce termination process rate) GFP and GUS gene (As reporter genes).

\subsection{Plant Materials}

Tobacco (Nicotiana tabacum $c v$. xanthi) was used. Young leaves were selected for tansformation. This cultivar (xanthi) is a model for gene transformation studies and is not used for cultivation (provided from Agricultural Biotechnology Laboratory of Tarbiat Modarres University, Tehran, Iran).

\subsection{Cloning of INF $\alpha-2 b$ Gene in pCAMBIA1304}

The INF $\alpha 2 b$ gene has been already cloned in the pALCA 
vector. This vector was used as a template for PCR. The gene was amplified using mentioned primers, and then, PCR product was extracted from the gel using QIAGEN kit. So, this was digested with BstEII and NcoI (NEB Co). The digested PCR product was extracted from gel using gel extraction kit again and then ligated with digested pCAMBIA1304 vector by T4 DNA ligase in $16^{\circ} \mathrm{C}$ overnight and the results were transformed to E. coli. Consequently, the INF $\alpha 2 b$ fragment was replaced in GUS- GFP region of pCAMBIA1304 under the control of the CaMV35s promoter and the NOS terminator by ligation process (Figure 1).

\subsection{Transformation of E. coli Using Heat Shock Method}

For transformation of recombinant vector to $E$. coli, $5 \mu \mathrm{l}$ of pCAMINF $\alpha$ binary vector was mixed with $1.5 \mathrm{ml}$ of competent cells of E. coli strain DH5 $\alpha$ and then transferred in a microtube and was put on ice for $30 \mathrm{~min}$. Vector was immediately submerged in bain-marie for 90 seconds at $42^{\circ} \mathrm{C}$ and then, was put on ice for $2 \mathrm{~min} .800 \mu \mathrm{l}$ of LB (Luria-Bertani Broth) was added to microtube. The culture was grown for one hour at $37^{\circ} \mathrm{C}$ on shaker. Eventually, $100 \mu \mathrm{l}$ of transformed cells were cultured on the LB plates containing $50 \mathrm{mg} / \mathrm{L}$ kanamycin. Plates were incubated for $16-18$ hours at $37^{\circ} \mathrm{C}(14)$. The pCAMINF $\alpha$ recombinant plasmid was verified by colony PCR (Figure 2), digestion and sequencing.

\subsection{Transformation of A. tumefaciens Using Thaw and Freezing Method}

A. tumefaciens strain LBA4404 was grown overnight at $28^{\circ} \mathrm{C}$ in liquid LB medium with $80 \mathrm{mg} / \mathrm{L}$ streptomycin. Agrobacterium culture spun down at $3500 \mathrm{rpm}$ for $10 \mathrm{~min}$ and resuspended in $100 \mu \mathrm{l}$ of $20 \mathrm{mM} \mathrm{CaCl} 2.5 \mu \mathrm{l}$ of vectors were added to suspension and mixed culture was submerged in liquid nitrogen and then in bain-marie for $5 \mathrm{~min}$ at $37^{\circ} \mathrm{C}$. One $\mathrm{ml}$ of $\mathrm{LB}$ was added and culture was grown for 3 hours in a $28^{\circ} \mathrm{C}$ shaker. $100 \mu$ l of transformed cells were cultured on the LB plates with a combination of $50 \mu \mathrm{g} / \mathrm{ml}$ kanamycin and $80 \mathrm{mg} / \mathrm{L}$ streptomycin. Plates were incubated for two days at $28^{\circ} \mathrm{C}(14)$ (Figure 3).

\subsection{Plant Transformation}

Tobacco plants were grown on MS medium (15) and the young leaves (length up to $4 \mathrm{~cm}$ ) were used for transformation of the Agrobacteria suspension (with OD600 nm
$=1.0$ ). The leaves were cut into 8-10 pieces and transferred to petri dishes containing MS II medium (MS medium supplemented with BAP and NAA) and incubated at $26^{\circ} \mathrm{C}$ in the dark for two days. Leaf pieces were transferred to MS III (MS II + $15 \mathrm{mg} /$ lit hygromycin $+200 \mathrm{mg} /$ lit of cephatoxim) plates and incubated at $25^{\circ} \mathrm{C}$ with a $16 / 8$ (day/ night) h photoperiod for three to four weeks. The shoots were removed and transferred onto MS IV (MS III without $\mathrm{NAA}+\mathrm{BAP}$ ) and incubated at $25^{\circ} \mathrm{C}$ with a $16 / 8$ (day/night) $\mathrm{h}$ photoperiod for 14 days until root was developed. The small plants were transferred into jar glasses containing MS IV and incubated at $25^{\circ} \mathrm{C}$ in a $16 / 8 \mathrm{~h}$ (day/night) light rhythm for two weeks. The tobacco plants were transferred to vase including perlite and were grown for two to three weeks. Finally, the plants were transferred to soil.

\subsection{Polymerase Chain Reaction (PCR) Analysis of Trans- genic Plant}

Genomic DNA of transgenic plants was extracted, using Dellaporta method (16). PCR amplification of genomic DNA in order to detect presence of INF $\alpha$-2b gene was carried out using primers described above, so plants with INF $\alpha$-2b gene were specified.

\subsection{Immunoblot Analysis}

Total soluble proteins were extracted from whole leaves. Dot blot analysis was performed on wild type and transgenic lines. Solution preparation and its methods were described by Roche Company which provides Anti-His6Peroxidase.10 ng protein samples were dotted on nitrocellulose membrane sheets. Then, western blocking solution $1 \mathrm{X}$ was added and incubated for one hour at $20^{\circ} \mathrm{C}$. Solution was washed out and replaced with Anti-His6Peroxidase. It was incubated for $90 \mathrm{~min}$, and then after the solution was poured out, washing with TBST1x was repeated three times for 5 min each time. Finally antibody and substrate were added. After colour development, the membranes were washed out with water and the colour changing was evaluated in both transgenic and control plants.

\section{Results}

\subsection{Plant Transformation}

Tobacco plants (cultivar xanthi) were inoculated with

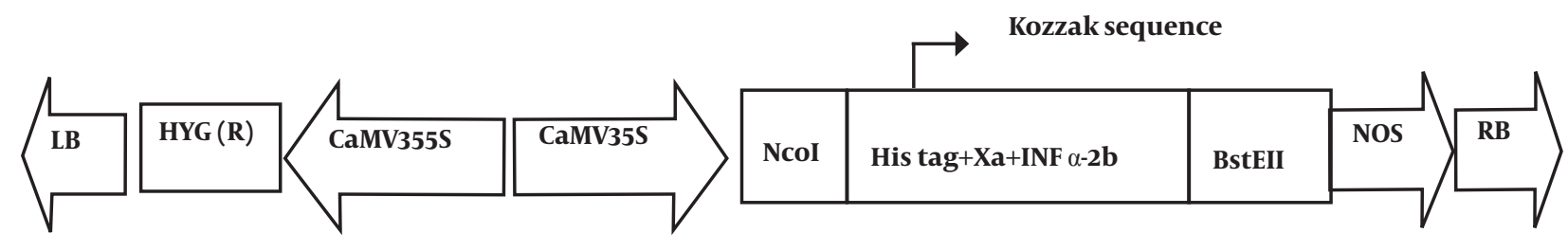

Figure 1. T-DNA Region of pCAMINFa-2b. LB and RB: Left and Right Borders, HYG(R): Hygromycin Selectable Marker, CaMV35s: Cauliflower Mosaic Virus Promoter, NcoI and BstEII: Restriction Sites and NOS: Nopaline Synthase Terminator. 


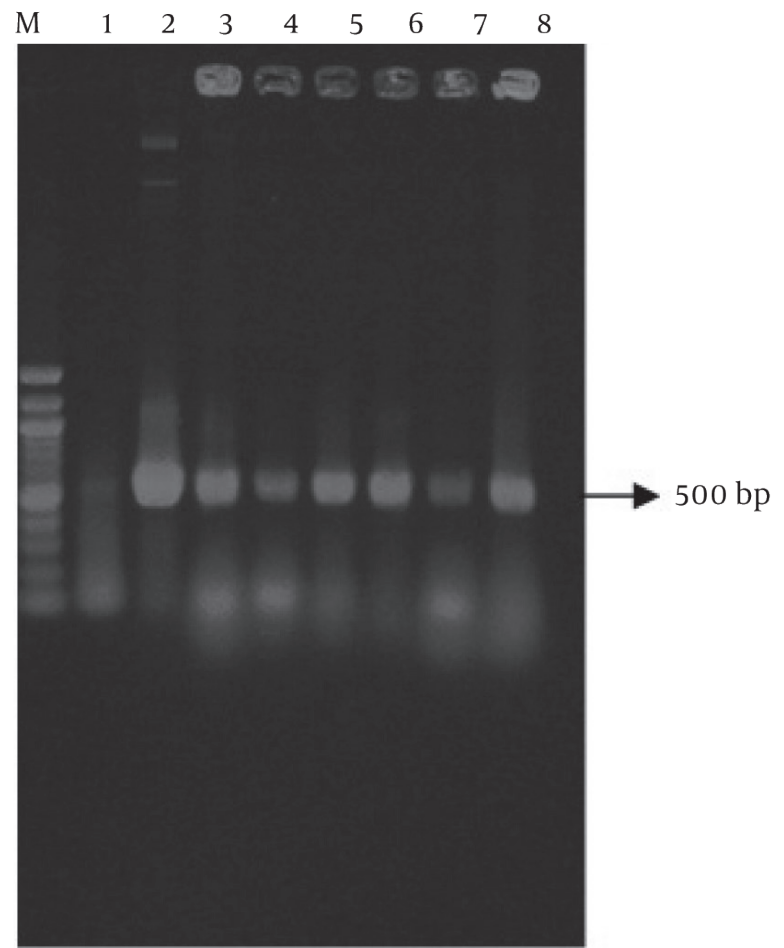

Figure 2. Confirmation of Cloning of INF $\alpha-2 b$ Gene in E. coli by Colony PCR Technique. M: GeneRuler ${ }^{\mathrm{TM}} 100$ bp DNA Ladder (Fermentase), Lane1: E. coli Without pCAMBIA-INF $\alpha$ (Negative Control), Lane 2: Positive Control (pCAMIFN $\alpha$ ), Lane 3-8: Random Colonies Selection.

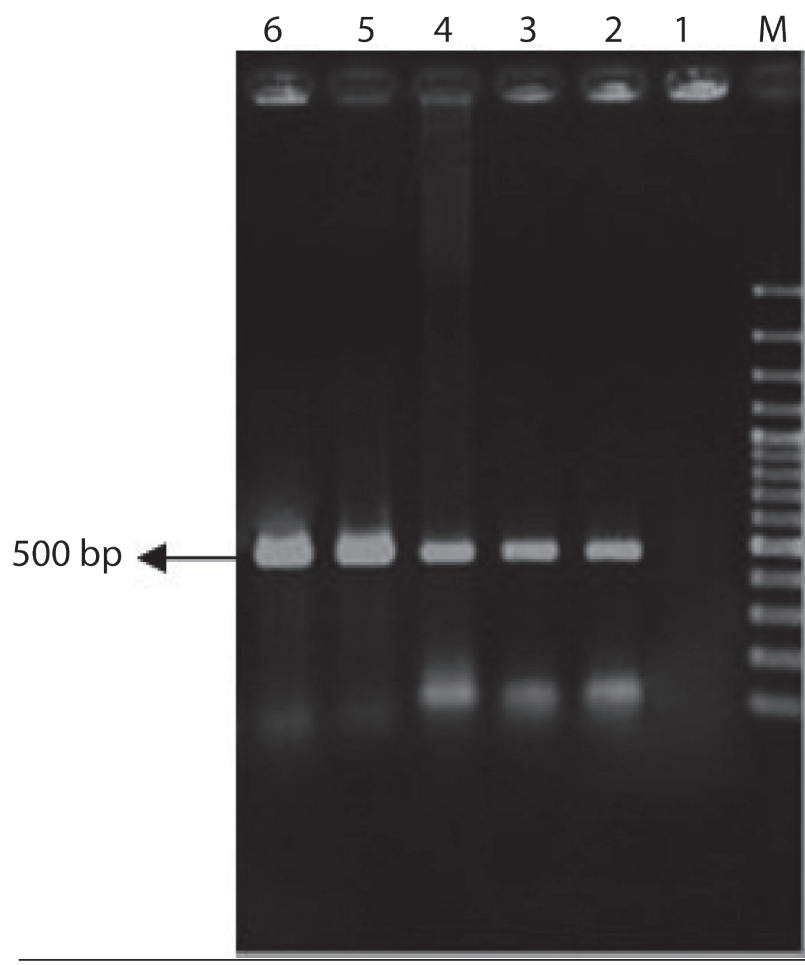

Figure 3. Confimation of INF $\alpha-2 b$ Gene in Agrobacterium by Colony PCR Technique. M: GeneRuler ${ }^{\mathrm{TM}} 100$ bp DNA Ladder (Fermentase), Lane1: Agrobacterium Without pCAMBIA-INF $\alpha$ (Negative Control), Lane 2: Positive Control (pCAMIFN $\alpha$ ), Lane 3-6: Random Colonies Selection.
A. tumefaciens strain LBA4404 by leaf disc method. Inoculated explants were cultured on MSII (MS+ BAP 1mgl-1 + NAA $0.1 \mathrm{mgl}-1$ ) at $28^{\circ} \mathrm{C}$ and darkness for 48 hours. Then explants were transferred to selection medium containing cephotaxime (250 mgl-1) and hygromycin (15 mgl-1) in a $16 \mathrm{~h}$ light and $8 \mathrm{~h}$ darkness rhythm in growth chamber. Transgenic plants were regenerated and transferred to soil (Figure 4).

\subsection{Extraction of Genomic DNA and PCR Analysis}

Genomic DNA of transgenic and control plants were extracted using Dellaporta method. The presence of INF $\alpha$ 2b gene in transgenic plant was proofed and detected using PCR technique, while control plants did not show any band on agarose gel electrophoresis (Figure 5).

\subsection{Protein Extraction and Confirmation of Gene Ex- pression}

The total extracted soluble proteins from both transgenic and wild type plants were used for immunedot blotting. The Figure 6 shows the results of the dot blot assay which confirms gene expression in transgenic plant. Screened transgenic lines as well as wild type plants were used for immunodot blot analysis. The expression of human interferon $\alpha 2 \mathrm{~b}$ which has His tag in the C-terminal

\section{Figure 4. Regeneration of Transgenic Tobacco (Nicotiana tabacum cultivar xanthi) Plants.}
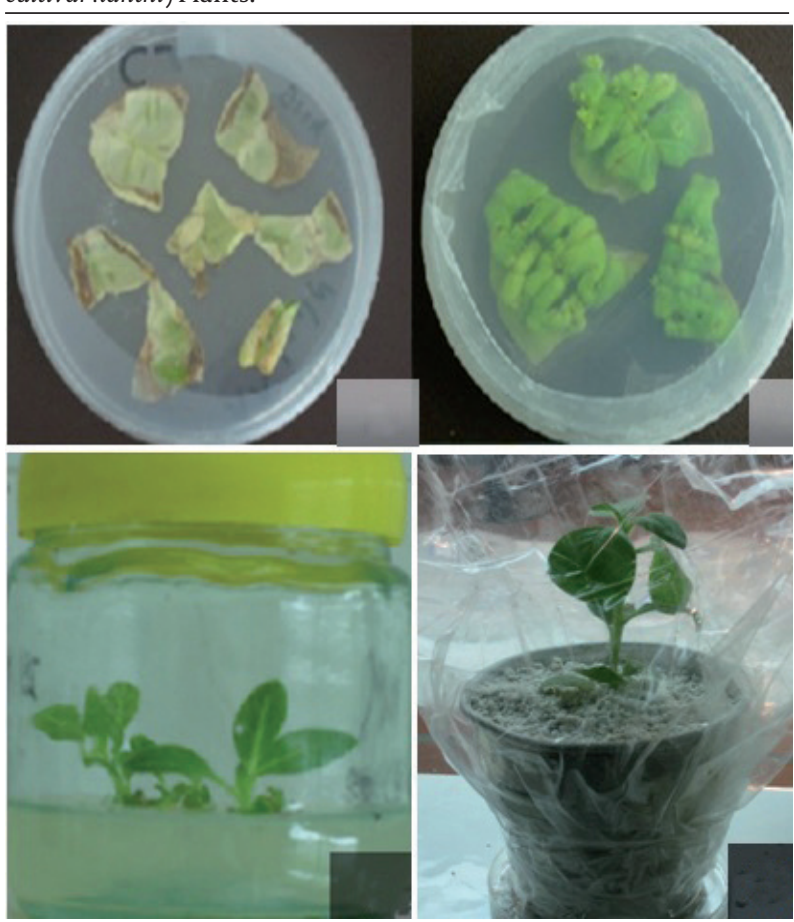

Leaves Were Inoculated by Agrobacterium tumefaciens, without pCAMINF $\alpha$ as Control (A) and With pCAMINF $\alpha$ (B) on MSIII Medium (MS $\mathrm{II}+15 \mathrm{mg} / \mathrm{lit}$ Hygromycin $+200 \mathrm{mg} / \mathrm{lit}$ Cephatoxim). Regeneration and Rooting on MSIV Medium (MS III Without Hormone) (C), Transporting to Perlite (D). 


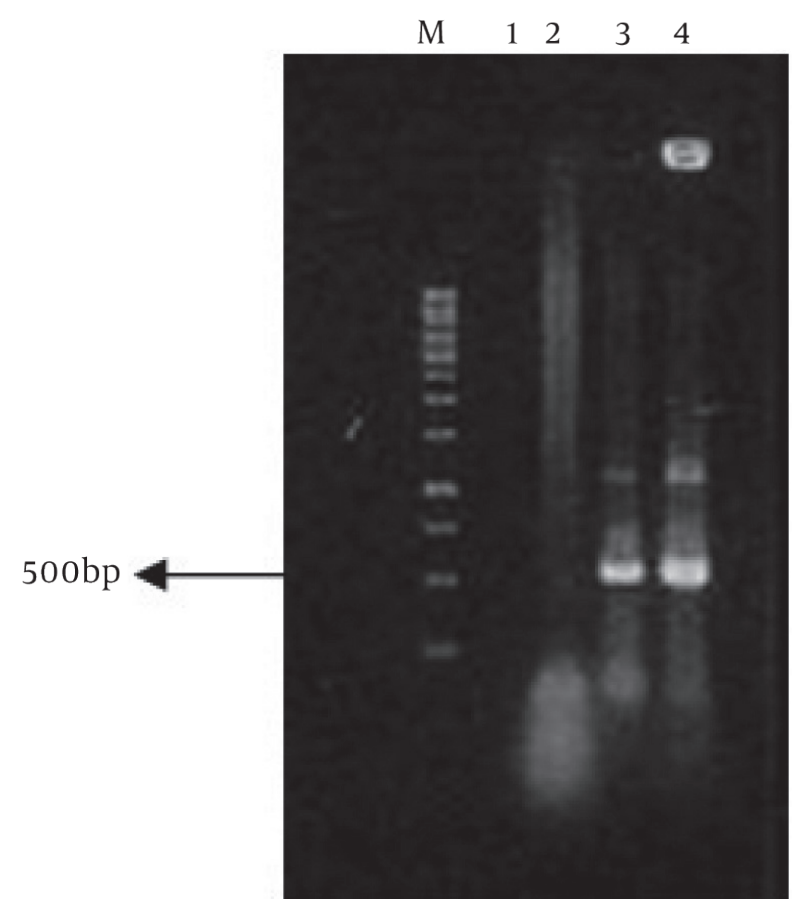

Figure 5. PCR Analysis of Transgenic Plants. M: 1kb Marker, Lane 1: ddH2O, Lane2: Wild Type Plant, Lane 3: Transgenic Plant, Lane 4: Positive Control (pCAMIFN $\alpha$ ).

\section{1}

Figure 6. Dot Blot Analysis of Protein Extraction of Tobacco. Lane 1: Protein Extraction of Negative Control Plants (Wild Type), Line 2: Protein Extraction of Transgenic Plant.

can be detected by anti His tag peroxidase and turn the substrate colour while the extracted protein from wild type plant did not show any turning colour in dot blot assay.

\section{Discussion}

Traditional production systems that use bacterial fermentation, insects and mammalian cell cultures, and transgenic animals have undergone drawbacks because of some reasons include; high expenses, scalability, product safety and authenticity (1). Producing of biopharmaceuticals in plants has some advantages compared to other prokaryotic and eukaryotic systems. So the use of plant expression platform as host for recombinant protein production has become more popular in research and development of new medicines (17). Both transient and stable expressions have been used for recombinant proteins expression in plants. The stable method was used in our study. Although the time for generating stable transgenic plants is more than transient expression however the transgenic tobacco plants can generate millions of seeds which can produce high quantity of recombinant proteins in next steps. In the present study, the binary vector, pCAMBIA1304 was used in plant transformation. This vector carries CaMV35S promoter and NOS terminator. In dicot plants, CaMV35S is a suitable promoter because it is strong and constitutive and can cause high level of transgenic expression in leaves, fruits, tubers, roots and other organs (18). Kozak sequence was used to boost the expression of INF $\alpha 2 \mathrm{~b}$ gene (19). His tag sequence is for recognition and purification of the interested protein from other proteins of a transgenic plant and factor $\mathrm{Xa}$ is for separation of the His tag from the purified interferon protein (20). As a model plant, tobacco benefits from well-established gene transfer and regeneration methodologies, and also the availability of many robust expression cassettes for the control of transgene expression. The Agrobacterium-mediated transformation is a method for transferring target genes into plants. The cocultivation of leaf discs with Agrobacterium can produce tobacco transformants with high quality and fertility (12). Considering of these advantages of plant systems in comparison with other systems, production of INF $\alpha-2 b$ in tobacco transgenic lines were done. Since no report of interferon alpha production in plants in Iran has been expressed yet, this research could create a field of producing this drug in tobacco, in Iran.

\section{Acknowledgements}

None declare.

\section{Financial Disclosure}

None declare.

\section{Funding/Support}

None declare.

\section{References}

1. Schillberg S, Emans N, Fischer R. Antibody molecular farming in plants and plant cells. Phytochem Rev. 2002;1(1):45-54.

2. Fischer R, Schillberg S. Molecular farming: Plant-made $\mathrm{pH}$ pharmaceuticals and technical proteins. Weinheim: Wiley-VCH verlag $\mathrm{GmbH} \& \mathrm{Co} . \mathrm{KGaA} ; 2004$.

3. Chelbi-Alix MK, Wietzerbin J. Interferon, a growing cytokine family: 50 years of interferon research. Biochimie. 2007;89(6-7):713-8.

4. Kurane I, Meager A, Ennis FA. Induction of interferon alpha and gamma from human lymphocytes by dengue virus-infected cells. J Gen Virol.1986;67 (Pt 8):1653-61.

5. Rubinstein M, Levy WP, Moschera JA, Lai CY, Hershberg RD, Bartlett RT, et al. Human leukocyte interferon: isolation and characterization of several molecular forms. Arch Biochem Biophys. 1981;210(1):307-18.

6. Lee SH, Kelley S, Chiu H, Stebbing N. Stimulation of natural killer cell activity and inhibition of proliferation of various leukemic 
cells by purified human leukocyte interferon subtypes. Cancer Res. 1982;42(4):1312-6.

7. Strander H, Mogensen KE, Cantell K. Production of human lymphoblastoid interferon. J Clin Microbiol. 1975;1(1):116-7.

8. Attallah AM, Fleisher TA, Hu R, Abdel-Gaffar H, Ibrahim S, Metwali A, et al. Immunological activities of recombinant interferon-alpha 2 and its A fragment. J Interferon Res. 1987;7(2):223-9.

9. Sen GC, Lengyel P. The interferon system. A bird's eye view of its biochemistry.J Jiol Chem. 1992;267(8):5017-20.

10. Maeda S, McCandliss R, Gross M, Sloma A, Familletti PC, Tabor JM, et al. Construction and identification of bacterial plasmids containing nucleotide sequence for human leukocyte interferon. Proc Natl Acad Sci U S A. 1980;77(12):7010-3.

11. Lund P, Dunsmuir P. A plant signal sequence enhances the secretion of bacterial ChiA in transgenic tobacco. Plant Mol Biol. 1992;18(1):47-53.

12. Bergmann L. Growth and division of single cells of higher plants in vitro. J Gen Physiol. 1960;43(4):841-51.

13. De La Riva GA, González-Cabrera J, Vázquez-Padrón R, Ayra-Pardo C. Agrobacterium tumefaciens: a natural tool for plant transfor- mation. Electron J Biotechn. 1998;1(3):24-5.

14. Sambrook J, Russell DW. Molecular cloning: a laboratory manual. CSHL press; 2001.

15. Murashige T, Skoog F. A revised medium for rapid growth and bio assays with tobacco tissue cultures. Physiol plantarum. 1962;15(3):473-97.

16. Dellaporta SL, Wood J, Hicks JB. A plant DNA minipreparation: version II. Plant Molec Biol. 1983;1(4):19-21.

17. Schillberg S, Fischer R, Emans N. 'Molecular farming' of antibodies in plants. Naturwissenschaften. 2003;90(4):145-55.

18. Kumar G, Ganapathi T, Bapat V. Production of hepatitis B surface antigen in recombinant plant systems: an update. Biotechnol Prog. 2007;23(3):532-9.

19. Rajabi Memari H, Ramanan RN, Ariff AB. Comparison of expression systems for the production of human interferon- $\alpha 2 \mathrm{~b}$. Cent EurJ Biol. 2010;5(4):446-55.

20. Leelavathi S, Reddy VS. Chloroplast expression of His-tagged GUS-fusions: a general strategy to overproduce and purify foreign proteins using transplastomic plants as bioreactors. Mol Breeding. 2003;11(1):49-58. 